Original Article

\title{
PRELIMINARY PHYTOCHEMICAL SCREENING, TOTAL PHENOL AND FLAVONOID CONTENT OF MIMOSA RUBICAULIS AND REINWARDITA INDICA
}

\author{
ROSHANI GURUNG ${ }^{*}$ \\ 1Department of Pharmacy, School of Health and Allied Sciences, Pokhara University, Lekhnath City, 33700, Nepal \\ Email: grg.rosni1990@gmail.com
}

Received: 30 Sep 2019, Revised and Accepted: 29 Nov 2019

\begin{abstract}
Objective: Phytochemicals as phenol and flavonoid have a powerful biological activity. So, this study aimed to carry out phytochemical screening, total phenol and flavonoid content in two plant species i.e. M. rubicaulis and $R$. indica.
\end{abstract}

Methods: The extraction of different parts of two plant species was done by maceration using ethanol. Phytochemical screening was done to confirm the presence of phytochemicals. Total phenol content was done by Folin ciocalteu method and total flavonoid content was done by Aluminium chloride colorimetric method.

Results: Phytochemical analysis revealed the presence of flavonoid, phenol, terpenoids in both plant species. The highest concentration of phenol content was observed in the root and stem of an extract of $M$. rubicaulis i.e. $281.83 \pm 1.98 \mathrm{mg} \mathrm{GAE} / \mathrm{g}$ dry extract weight and $225.37 \pm 0.60 \mathrm{mg}$ GAE$/ \mathrm{g}$ dry extract weight. The highest concentration of flavonoid contents was observed in the leaves of $R$. indica i.e. $462.21 \pm 4.67 \mathrm{mg} \mathrm{QE} / \mathrm{g}$ dry extract weight followed by stem and root of $M$. rubicaulis i.e. $381.06 \pm 5.23 \mathrm{mg} \mathrm{QE} / \mathrm{g}$ dry extract weight and $337.43 \pm 1.39 \mathrm{mg}$ QE/g dry extract weight.

Conclusion: Phytochemical analysis concluded the presence of biologically important phytoconstituents like flavonoid and phenol in both plant species. Further studies, should be carried out to isolate specific chemical constituents and should be used in different studies to explore their biological effects.

Keywords: Mimosa rubicaulis, Reinwardita indica, Phytochemical Screening, Total Phenol Content, Total Flavonoid Content, Quercetin, Gallic acid

(C) 2020 The Authors. Published by Innovare Academic Sciences Pvt Ltd. This is an open-access article under the CC BY license (http://creativecommons.org/licenses/by/4.0/) DOI: http://dx.doi.org/10.22159/ijpps.2020v12i1.35914. Journal homepage: https://innovareacademics.in/journals/index.php/ijpps

\section{INTRODUCTION}

Medicinal plants are the greatest source of all kinds of medicines including a traditional system of medicines, modern medicines, nutraceuticals and compounds for new chemical entities because it contains different types of phytochemicals or secondary metabolites [1]. Alkaloids, flavonoids, phenols, tannins, glycosides, terpenoids, etc are mostly found secondary metabolites or phytochemicals in plant sources like fruits, vegetables, beans, cereals, and plant-based beverages such as tea, wine, etc [2] and are synthesized by primary or rather secondary metabolism of living organisms [3]. Phytochemicals are important because it gives protection to plant and also possesses several pharmacological activities, so they can be used for the treatment of various kinds of diseases [4]

Phenol consists of an $\mathrm{OH}$ (Hydroxyl group) bonded directly to aromatic hydrocarbon groups. They are secondary metabolites in plants and exhibit health beneficial activities such as antioxidant, anti-inflammatory, antihepatotoxic, antitumor and antimicrobial [5]. Phenols have potent antioxidant properties due to the presence of hydroxyl and carboxyl group, they can bind to the free radicals and deactivate them along with the ability to donate electron or the hydrogen atom to the unpaired free radicals [6].

Flavonoids are hydroxylated phenolic substances and are known to be synthesized by plants in response to microbial infection [7]. Flavonoid is derived from the Latin word flavus, which means yellow, their color in, and structurally flavonoids are classified as flavones (Myricetin, Quercetin, Rutin, Kaempferol), flavanones (Naringenin, Fisetin), catechins (Catechin, Epicatechin), and anthocyanins (Cyanidin, Peonidin, Malvidin)[8]. A different study suggested that flavonoids possess different biological activity as antioxidants, anti-inflammatory, antiallergic, antimutagenic, antiviral, antineoplastic, antithrombotic activity, antihepatotoxic, antitumoral, and antimicrobial [9]. Flavonoids may also act as chemical messengers, physiological regulators and cell cycle inhibitors, protection of certain cell types, for example, red blood cells, reduce capillary hyperpermeability by protecting the micro- circulation from inflammatory processes $[6,10-12]$. But the specific function of many phytochemicals is still unclear. However, a considerable number of studies have shown that they are involved in the interaction of plants/pests/diseases [13].

Due to the safe and effective results of plant source as medicine and strong evidence of biological activities of phenolic compounds, the study was focused on the determination of total phenolics and flavonoids content in two plant species i.e. Mimosa rubicaulis (Leguminosae) and Reinwardita indica (Linaceae). Traditionally these two plant species are used in peptic ulcer, dislocated bone, sprains, backache, hemorrhoids, wound, fever, boils, headaches, scabies [14] but the literature related to the phytochemical screening, total phenol, and flavonoid content in this two species is lacking till the date.

\section{MATERIALS AND METHODS}

\section{Chemicals}

Aluminium Chloride (Qualigens Fine Chemicals, India), FolinCiocalteu Reagent (Qualigens Fine Chemicals, India), Quercetin (Qualigens Fine Chemicals, India), Gallic Acid (Wako Pure Chemical Industries, Ltd., Japan) and all the other required chemicals were obtained from the laboratory of School of Health and Allied Sciences, Pokhara University, Lekhnath-12, Kaski, Nepal. All chemicals and reagents used were of analytical grade.

\section{Plant materials}

Whole plants of $M$. rubicaulis and R. indica were collected from different regions of Pokhara valley, Nepal by the proper identification under the supervision of local traditional healers. Then the root, stem, and leaves of M. rubicaulis, flower, and leaves of $R$. indica were separated from unnecessary parts of plants.

\section{Identification of crude drug}

A specimen of the plant was used to prepare herbarium and properly identified by the botanist Prof. Dr. Radhe Shyam Kayastha. Then, a sample of crude drugs were preserved in Pharmacognosy Laboratory of School of Health and Allied Sciences, Pokhara University, Nepal. 


\section{Drying of the crude drug}

The collected crude samples were dedusted and cleaned properly, cut into small pieces and shade dried.

\section{Extraction}

Different parts of plants were extracted by maceration process using ethanol as solvent. Shade dried samples were first ground into fine powders. Then, $25 \mathrm{~g}$ of each sample was weighed and macerated in $175 \mathrm{ml}$ ethanol (ethanol: crude drug= 7:1) for $24 \mathrm{~h}$. After $24 \mathrm{~h}$, filtration was done by using filter paper and the obtained residue was again macerated with $175 \mathrm{ml}$ i.e. the same volume of ethanol for $24 \mathrm{~h}$. Then, obtained filtrates were mixed and dried by using a rotatory vacuum evaporator and collected in the Petri dish. Again that, samples were kept in a vacuum desiccator for the complete removal of solvent present in the extract. The obtained dried extracts were collected in a sample vial and preserved in the refrigerator. Extractive yield for each sample was determined by using formula;

$\%$ Yield $=$ Weight of extract $/$ Weight of crude sample taken $\times 100 \%$

\section{Qualitative phytochemical screening}

Phytochemical screening of ethanolic extract (root, stem, and leaves) of $M$. rubicaulis and (flower and leaves) of $R$. indica were carried out to reveal the presence of secondary metabolites according to the method described previously with some modification [15].

\section{Quantitative phytochemical screening}

\section{Determination of total phenol contents}

Folin ciocalteu method was used for the determination of total phenol content according to the method of [16] with some modifications. In brief, $1 \mathrm{ml}$ of sample was mixed with $5 \mathrm{ml}$ of distilled water and $1 \mathrm{ml}$ of Folin reagent. After standing for $5 \mathrm{~min}, 1$ $\mathrm{ml}$ of $10 \%$ sodium carbonate was added and stirred. The mixture was incubated for $1 \mathrm{~h}$ at room temperature and the absorbance was measured at $725 \mathrm{~nm}$ against a blank. The total phenol content expressed as mg of GAE (Gallic Acid Equivalent) per g dry extract weight using the calibration curve of Gallic acid $(50 \mathrm{mg} / \mathrm{l}-500 \mathrm{mg} / \mathrm{l})$ standards.

\section{Determination of total flavonoid contents}

The aluminium chloride colorimetric method was used for flavonoids determination according to the method of [17] with some modifications. In brief, $1 \mathrm{ml}$ of the sample solution was mixed with 4 $\mathrm{ml}$ of distilled water. Then, $300 \mu \mathrm{l}$ of sodium nitrite was added. After $5 \mathrm{~min}, 300 \mu \mathrm{l}$ aluminium chlorides were added and allowed to stand for $6 \mathrm{~min}$. Then, $2 \mathrm{ml}$ of sodium hydroxide was added. The mixture was stirred and the absorbance was measured at $510 \mathrm{~nm}$ using UV spectrophotometer and compared with standard. The total flavonoids content expressed as mg QE (Quercetin Equivalent) per g dry extract weight using a calibration curve of Quercetin $(50 \mathrm{mg} / \mathrm{l}$ $500 \mathrm{mg} / \mathrm{l}$ ) standards.

\section{Data analysis}

The experimental data obtained were expressed as mean \pm standard deviation.

\section{RESULTS}

\section{Extraction yield value}

The extract yield percentage of the plant sample was given in table 1 . The extract yield percentage was relatively higher in root and leaves of M. rubicaulis, and flower of R. indica while relatively lower in the stem of M. rubicaulis and leaves of $R$. indica.

Table 1: List of sample for the study with their extraction yield value in ethanol

\begin{tabular}{llll}
\hline Scientific name & Parts used & Sample code & \% Yield value (Ethanol) \\
\hline Mimosa rubicaulis & Root & A & 8 \\
& Stem & B & 3.2 \\
& Leaves & C & 11.52 \\
Reinwardita indica & Flower & D & 7.95 \\
& Leaves & E & 3.52 \\
\hline
\end{tabular}

Table 2: Phytochemical analysis of the selected parts of plants

\begin{tabular}{|c|c|c|c|c|c|c|c|c|}
\hline \multirow{2}{*}{$\begin{array}{l}\text { S. } \\
\text { No. }\end{array}$} & \multirow{2}{*}{$\begin{array}{l}\text { Phytochemical } \\
\text { test }\end{array}$} & \multirow[t]{2}{*}{ Test performed } & \multirow[t]{2}{*}{ Inferences } & \multicolumn{3}{|c|}{ Mimosa rubicaulis } & \multicolumn{2}{|c|}{ Reinwardita indica } \\
\hline & & & & $\begin{array}{l}\text { Root } \\
\text { extract }\end{array}$ & $\begin{array}{l}\text { Stem } \\
\text { extract }\end{array}$ & $\begin{array}{l}\text { Leaves } \\
\text { extract }\end{array}$ & $\begin{array}{l}\text { Flower } \\
\text { extract }\end{array}$ & $\begin{array}{l}\text { Leaves } \\
\text { extract }\end{array}$ \\
\hline \multirow[t]{3}{*}{1} & Alkaloid & Mayer's Reagent & Appearance of yellow cream ppt. & - & - & - & - & - \\
\hline & & Wagner's Reagent & $\begin{array}{l}\text { Formation of brown/reddish } \\
\text { brown ppt. }\end{array}$ & - & - & - & - & - \\
\hline & & Hager's Reagent & Formation of yellow color ppt. & - & - & - & ++ & + \\
\hline \multirow[t]{2}{*}{2} & Glycosides & $\begin{array}{l}\text { Modified } \\
\text { Borntrager's test }\end{array}$ & Formation of rose pink color & -- & - & - & - & - \\
\hline & & Legal's test & Formation of pink to blood-red color & - & - & - & + & - \\
\hline 3 & Flavonoids & Alkaline Reagent Test & No intense yellow color obtained & + & + & - & + & + \\
\hline \multirow[t]{3}{*}{4} & Carbohydrates & Molish's Reagent & $\begin{array}{l}\text { Formation of violet ring at the } \\
\text { junction }\end{array}$ & + & + & + & +++ & ++ \\
\hline & & Benedict's Reagent & Formation of orange red ppt. & ++ & +++ & + & + & + \\
\hline & & Fehling's Reagent & Formation of red ppt. & ++ & +++ & + & + & + \\
\hline 5 & Saponins & Foam Test & $\begin{array}{l}\text { Produced foam lasts for more than } \\
10 \text { min }\end{array}$ & ++ & - & - & - & - \\
\hline 6 & Tannins & Gelatin Test & Formation of white ppt. & + & + & - & - & - \\
\hline 7 & Resin Test & Acetone water Test & Appearance of turbidity & + & + & - & + & - \\
\hline 8 & Phenol test & Ferric chloride Test & Appearance of bluish black ppt. & ++ & ++ & + & + & + \\
\hline 9 & Terpenoids & Salkowski's Test & $\begin{array}{l}\text { Appearance reddish brown } \\
\text { precipitates }\end{array}$ & ++ & ++ & + & - & + \\
\hline 10. & $\begin{array}{l}\text { Proteins and } \\
\text { aminoacid test }\end{array}$ & Xanthoproteic Test & Formation of yellow color & + & + & - & + & + \\
\hline 11. & $\begin{array}{l}\text { Fixed oils and } \\
\text { Fats test }\end{array}$ & $\begin{array}{l}\text { Filter paper press } \\
\text { Test }\end{array}$ & $\begin{array}{l}\text { Appearance of oily stain on filter } \\
\text { paper }\end{array}$ & + & + & + & ++ & ++ \\
\hline
\end{tabular}

Note: +++: Strong intensity reaction,++: Medium intensity reaction,+: Weak intensity reaction, -: Non detected 


\section{Qualitative phytochemical analysis}

The qualitative phytochemical analysis revealed the presence of flavonoid, phenol, carbohydrate, resin, protein, fixed oil, and terpenoids in the ethanolic extract of both plant species i. e $M$. rubicaulis and $R$. indica but alkaloid was absent in M. rubicaulis extract and glycoside was absent in both $M$. rubicaulis and $R$. indica extract which had been tabulated in table 2 .

\section{Total phenol contents}

The calibration curve of Gallic acid as standard at concentrations $50 \mathrm{mg} / \mathrm{l}, 100 \mathrm{mg} / \mathrm{l}, 200 \mathrm{mg} / \mathrm{l}, 300 \mathrm{mg} / \mathrm{l}, 400 \mathrm{mg} / \mathrm{l}$, and $500 \mathrm{mg} / \mathrm{l}$, as shown in fig. 1 . The total phenolic content of the different extract was expressed as mg of GAE per g dry extract. The highest concentration of phenol content was observed in root and stem of extract of $M$. rubicaulis i.e. $281.83 \pm 1.98 \mathrm{mg} \mathrm{GAE} / \mathrm{g}$ dry extract weight and $225.37 \pm 0.60 \mathrm{mg} \mathrm{GAE} / \mathrm{g}$ dry extract weight and the lowest concentration of phenol content was observed in flower extract of $R$. indica i.e. $24.33 \pm 0.26 \mathrm{mg} \mathrm{GAE} / \mathrm{g}$ dry extract weight as shown in table 3.

\section{Total flavonoid contents}

The total flavonoid content was performed by precipitating with aluminium chloride in an alkalinized medium. Quercetin was taken as standard and the calibration curve of Quercetin as at concentrations $50 \mathrm{mg} / \mathrm{l}, 100 \mathrm{mg} / \mathrm{l}, 200 \mathrm{mg} / \mathrm{l}, 300 \mathrm{mg} / \mathrm{l}, 400 \mathrm{mg} / \mathrm{l}$, and $500 \mathrm{mg} / \mathrm{l}$ as shown in fig. 2 . The highest concentration of flavonoid contents were observed in the leaves of $R$. indica i.e. $462.21 \pm 4.67 \mathrm{mg} \mathrm{QE} / \mathrm{g}$ dry extract weight followed by stem and root of $M$. rubicaulis i.e. $381.06 \pm 5.23 \mathrm{mg} \mathrm{QE} / \mathrm{g}$ dry extract weight and $337.43 \pm 1.39 \mathrm{mg} \mathrm{QE} / \mathrm{g}$ dry extract weight The lowest concentration of flavonoid content was observed in the leaves of M. rubicaulis i.e. $159.85 \pm 5.23 \mathrm{mg} \mathrm{QE} / \mathrm{g}$ dry extract weight. The total flavonoid contents of plant extract were listed in table 4 .

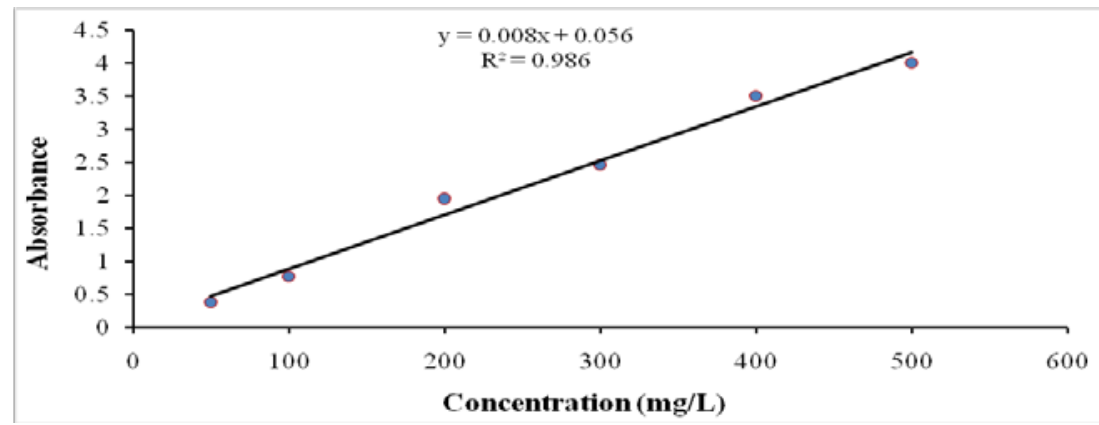

Fig. 1: Calibration curve of Gallic acid for total phenol calculation

Table 3: Total phenol content expressed as mg GAE per g dry extract

\begin{tabular}{lll}
\hline S. No. & Sample & Total phenol content (mg GAE/g dry weight of extract) \\
\hline 1. & A & $281.83 \pm 1.98$ \\
2. & B & $225.37 \pm 0.60$ \\
3. & C & $130.86 \pm 0.09$ \\
4. & D & $24.33 \pm 0.26$ \\
5. & E & $79.33 \pm 0.17$ \\
\hline
\end{tabular}

Data expressed as a mean \pm standard deviation for three experiments. Total Phenol content was calculated with the help of the calibration curve of Gallic acid as standard.

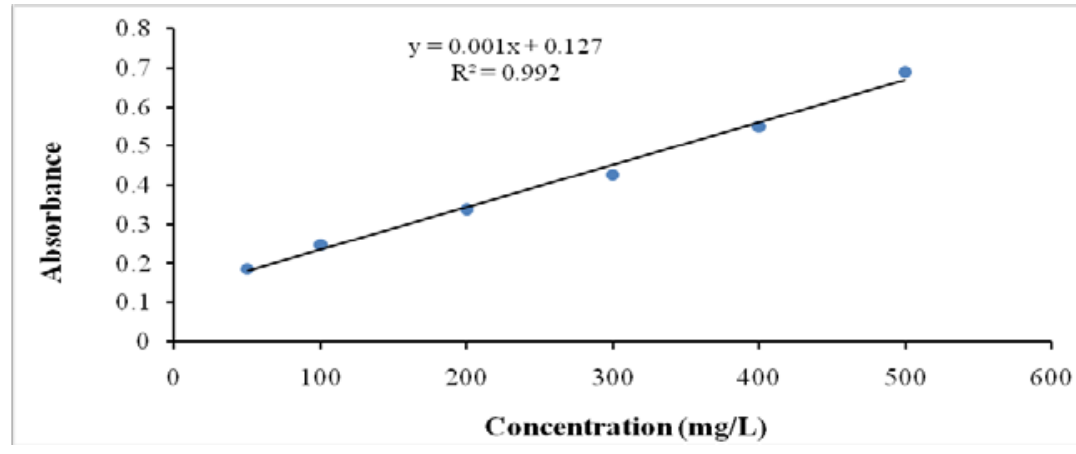

Fig. 1: Calibration curve of Quercetin for total flavonoid calculation

Table 4: Total favonoid content expressed as QE per g dry extract

\begin{tabular}{lll}
\hline S. No. & Sample & Total flavonoid content (mg QE/g dry weight. extract) \\
\hline 1 & A & $337.43 \pm 1.39$ \\
2 & B & $381.06 \pm 5.23$ \\
3 & C & $159.85 \pm 5.23$ \\
4 & D & $194.09 \pm 0.91$ \\
5 & E & $462.21 \pm 4.67$ \\
\hline
\end{tabular}

Data expressed as mean \pm standard deviation for three experiments. Total flavonoid content was calculated with the help of the calibration curve of Quercetin as standard. 


\section{DISCUSSION}

Phytochemical screening is done to reveal the presence of important phytoconstituent in plant samples, which helps in discovering of novel drugs having any pharmacological activity [18] and finding out the ingenuity of drug [19]. This study revealed the presence of flavonoid, phenol, tannin, carbohydrates, etc. in both species. It showed that most of the biologically active constituents are present in both plant species. This study showed a similar observation done in the previous in methanolic extract of M. rubicaulis as the presence of flavonoids like quercetin, lutein, and tannin [9].

Phenol is a secondary metabolite and has free radical scavenging activity due to the presence of the hydroxyl group. The phenolic compounds from the sample cause the reduction of heteropoly acids (Phosphomolybdate-phosphotungstate) contained in Folin-ciocalteu reagent that changes from yellow color to Prussian blue which can be measured in absorbance at $725 \mathrm{~nm}$ [20]. So, the intensity of the blue color is directly proportional to the phenolic content [5]. In this study, phenol content was found to be high in root and stem of $M$. rubicaulis i.e. $281.83 \pm 1.98 \mathrm{mg} \mathrm{GAE} / \mathrm{g}$ dry extract weight and $225.37 \pm 0.60 \mathrm{mg} \mathrm{GAE} / \mathrm{g}$ dry extract weight. Those parts of plant extracts which showed better antioxidant activity have higher phenol content. But $R$. indica contains lower phenol contents, This observation is comparatively lower than the previous study done on aqueous and methanolic extracts of $R$. indica leaves, which showed a significant total phenolic content DPPH (2,2-diphenyl-1picrylhydrazyl) and anion scavenging activity [21].

Flavonoid is one of the most widespread and important secondary metabolites that possess various biological activities i.e. they are good scavengers of the most oxidizing molecule, including singlet oxygen, and various free radicals [22]. The total flavonoid content was determined by using the aluminium chloride colorimetric method. Flavonoid in the presence of aluminium chloride has intense yellow fluorescence which is observed in the UV spectrometer at $510 \mathrm{~nm}$ [17]. Among the plant extracts studied, total flavonoid contents were found to be high in leaves of $R$. indica followed by stem and root of $M$. rubicaulis i.e. $462.21 \pm 4.67 \mathrm{mg} \mathrm{QE} / \mathrm{g}$ dry extract weight, $381.06 \pm 5.23 \mathrm{mg} \mathrm{QE} / \mathrm{g}$ dry extract weight, and $337.43 \pm 1.39 \mathrm{mg} \mathrm{QE} / \mathrm{g}$ dry extract weight. There is no correlation between phenolic content and flavonoid content of leaves extract of $R$. indica. This indicates that the leaves of $R$. indica may contain the flavonoids without the $\mathrm{OH}$ in aromatic benzene ring [23].

So, plants containing phenolic and flavonoids compound are of interest in the biological research for the discovery of novel leads molecules [24, 25].

\section{CONCLUSION}

Both qualitative and quantitative phytochemical analysis concluded the presence of biologically important phytoconstituents like flavonoid and phenol in the ethanolic extract of both plant species. So, these two plant species could be used as a natural antioxidant, anti-inflammatory, wound healing agent, etc. In further, a different study should be carried out to isolate specific chemical constituents as well as to explore their biological effects in the proper scientific ways which could be beneficial in the treatment and controlling of various diseases.

\section{ACKNOWLEDGMENT}

The author would like to acknowledge the Department of Pharmacy, School of Health and Allied Sciences, Pokhara University, for providing necessary facilities to carry out this work.

\section{FUNDING}

Nil

\section{AUTHORS CONTRIBUTIONS}

Roshani Gurung: Literature search, done all the experiments, done data analysis, done designing of the draft for the manuscript, wrote the first draft, done review and editing of the draft.

\section{CONFLICT OF INTERESTS}

The author declares no conflict of interest.

\section{REFERENCES}

1. Amad M, Wajid M. Plants as a potential source of antimicrobial agents. J Pharm Alter Med 2013;2:18-25.

2. Newman DJ, Cragg GM, Snader KM. Natural products as a source of new drugs over the period. J Nat Prod 2003;66:1022-37.

3. Yadav RNS, Agarwala M. Phytochemical analysis of some medicinal plants. J Phytol 2011;3:10-4.

4. Rawat P, Bachheti RK, Kumar N, Rai N. Phytochemical analysis and cvaluation of in vitro immunomodulatory activity of Rhododendron arboreum leaves. Asian J Pharm Clin Res 2018;11:123-8.

5. Figueroa LA, Navarro LB, Vera MP, Petricevich VL. Antioxidant activity, total phenolic and flavonoid contents, and cytotoxicity evaluation of Bougainvillea xbuttiana. Int J Pharm Pharm Sci 2014;6:497-2.

6. Antolovich M, Prenzler PD, Patsalides E, Mc Donald S, Robards K. Methods for testing antioxidant activity. Analyst 2001;127:183-98.

7. Dixon RA, Dey PM, Lamb CJ. Phytoalexins: enzymology and molecular biology. Adv Enzymol Relat Areas Mol Biol 1983;55:69.

8. Nijveldt RJ, Van Nood EL, Van Hoorn DE, Boelens PG, Van Norren K, Van Leeuwen PA. Flavonoids: a review of probable mechanisms of action and potential applications. Am J Clin Nutr 2001;74:418-25.

9. Khan AM, Qureshi RA, Faizan Ullah F, Shinwari ZK, Khan J. Flavonoids distribution in selected medicinal plants of margalla hills and surroundings. Pak J Bot 2012;44:1241-5.

10. Khan AM, Qureshi RA, Ullah F, Gilani SA, Nosheen A, Sahreen S, et al. Phytochemical analysis of selected medicinal plants of margalla hills and surroundings. J Med Plants Res 2011;5:6017-23.

11. Luis A, Domingues F, Gil C, Duarte AP. Antioxidant activity of extracts of portuguese shrubs: Pterospartum tridentatum, Cytisus scoparius and Erica spp. J Med Plants Res 2009;3:886-93.

12. Misra MC. Drug treatment of hemorrhoids. Drugs 2005;65:1481-91.

13. Shakeri A, Hazeri N, Vlizadeh J, Ghasemi A, Tavallaei FZ. Phytochemical screening, antimicrobial and antioxidant activities of Anabasis aphylla L. extracts. Kragujevac J Sci 2012;34:71-8.

14. Manandhar NP. Plants and people of Nepal. Portland: Timber Press; 2002. p. 117, 320, 421 .

15. Kodangala C, Saha S, Kodangala P. Phytochemical studies of aerial parts of the plant Leucas lavandulaefolia. Pharm Chem 2010;2:434-7.

16. Pourmorad F, Hosseinimehr SJ, Shahabimajd N. Antioxidant activity, phenol and flavonoid contents of some selected Iranian medicinal plants. Afr J Biotechnol 2006;5:1142-5.

17. Chang CC, Yang MH, Wen HM, Chern JC. Estimation of total flavonoid content in propolis by two complementary colorimetric methods. J Food Drug Anal 2002;10:178-82.

18. Dutta J. Phytochemical analysis and TLC fingerprinting of methanolic extract of three medicinal plants. Int Res J Pharm 2013;4:123-6.

19. Kala C, Ali SS, Chaudhary S. Comparative pharmacognostical evaluation of Costus speciosus (Wild ginger) and Zingiber officinale (ginger) rhizome. Int J Curr Pharm Res 2016;8:19-23.

20. Alawiyah AL, Achmadi SS, Syahbirin G. Total phenolic content and flavone bioactivity of peanut hulls as antioxidant and antiproliferation toward Henrietta Lacks cancer cells. Asian J Pharm Clin Res 2017;10:144-9.

21. Rawat A, Rana PS, Molpa D, Saklani P. Phytochemical composition and antioxidant activity of Reinwardtia indica from a selected location of Uttrakhand. Int J Prog Eng Manag Sci Hum 2015;1:22-9.

22. Jebitta SR, Allwin SJ. Antioxidant activity, total phenol, flavonoid and anthocyanin contents of jamun (Syzygium cumini) pulp powder. Asian J Pharm Clin Res 2016;9:361-3.

23. Atanassova M, Georgieva S. Comparative polyphenol composition and antioxidant capacity of the Bulgarian plants (Dry Herbs). Electron J Environ Agric Food Chem 2010;9:1514-23. 
24. Aryal S, Baniya MK, Danekhu K, Puspa Kunwar, Gurung R, Koirala N. Total phenolic content, flavonoid content and antioxidant potential of wild vegetables from Western Nepal. Plants 2019;8:96.
25. Bahorun T, Luximon Ramma A, Crozier A, I Aruoma O. Total phenol, flavonoid, proanthocyanidin and vitamin $C$ levels and antioxidant activities of mauritian vegetables. J Sci Food Agric 2004;84:1553-61. 